\title{
Challenges and Countermeasures of Climate Risk to Bank's Asset-Liability Management
}

\author{
Yufeng Guo \\ Fuqua School of Business, Duke University, 100 Fuqua Drive, Durham, NC, U.S. \\ Yufeng.guo@alumni.duke.edu
}

\begin{abstract}
In the context of global warming and carbon neutrality, climate risk is affecting the management and business strategies of many industries. For commercial banks, climate risk may have certain impacts on the asset side and liability side of bank's balance sheet at the same time. Therefore, banks need an overall asset-liability management strategy for transition to a low-carbon economy to realize the transformation of asset structure to green assets and the stability of liability side cost under the background of carbon neutrality, so as to realize the sustainable operation of commercial banks under the challenge of climate risk. Based on the challenges of commercial banks' operation and management under the background of carbon neutrality, taking the impact of climate risk on bank asset liability management as the starting point, this paper analyzes the transmission path of climate risk on existing risk categories of banks, summarizes the two major challenges of climate risk on asset-liability management, puts forward corresponding strategic suggestions, and concludes the current international best practices in managing climate risk.
\end{abstract}

Keywords: Carbon neutralization, Climate risk, Asset liability management, Sustainable development.

\section{Introduction}

Climate risk mainly refers to the risk caused by extreme weather, natural disasters, global warming and the transformation of society to a more economic sustainable development type. Internationally, climate risks faced by financial institutions are mainly divided into physical risks and transformation risks [1] (pp. 44-46, 2021, Liu Ruixia). Physical risk refers to the risk that climate related events damage the bank's balance sheet and directly lead to the loss of bank assets. Transformation risk refers to the financial risk caused by changes in asset prices due to changes in regulatory policies, restrictions on old technologies, breakthroughs in new technologies, changes in market preferences, changes in legal compliance and other factors during the transformation of banks to a low-carbon economy [2] (pp. 96-98, 2021, Liu Xiaoshu, Yang Jingcheng).

The Financial Stability Board (FSB) established the Taskforce on Climate-related Financial Disclosures (TCFD) in December 2015. TCFD stressed that climate risk itself is a financial risk for financial institutions. The guidelines for climate risk management were subsequently issued in October 2020. On April 15, 2021, at the high-level seminar on the theme of "green finance and climate policy", Yi Gang, President of the People's Bank of China, said that the People's Bank of China is considering the impact of climate risk factors on policy formulation, and will further actively explore the systematic and comprehensive consideration of climate change factors in the stress test of financial institutions, and gradually integrate the climate change risk management system into the Macro Prudential Policy framework. For domestic commercial banks, the challenge of climate risk to asset-liability management of commercial banks should not be underestimated. Whether it is regulatory requirements or business transformation needs, it is urgent to integrate climate risk into corporate governance, risk management and bank-wide strategy. Banks should also measure the impact of climate risk from the perspective of bank-wide asset-liability management, and formulate corresponding management strategies.

\section{Transmission Path}

Climate risk is generally divided into physical risk and transition risk. The mechanisms of the two risks on the bank's assets and liabilities are different. The transmission paths of these two risks to banks are analyzed respectively below:

\subsection{Physical Risk}

Physical risk mainly affects the stability of the bank's asset side. There are three transmission paths:

\section{1) Liquidity channel}

On the asset side, physical risk may reduce the frequency of economic activities, increase the borrower's probability of default and affect the inflow of bank's cash flow. From the liability side, the physical risk may also trigger additional capital demand of enterprises and residents, thus reducing the liquidity of the market, resulting in the rise of the interbank borrowing market interest rate, which is affected by the relationship between capital supply and demand. The high liability cost weakens the bank's ability to absorb funds and further increases the bank's liquidity risk

\section{2) Collateral channel}

Physical risk may damage or devalue the collateral, thus indirectly or directly affecting the borrower's repayment ability, increasing the borrower's probability of default and loss given default (LGD), and affecting the quality and return rate of the asset held by the bank. At the same time, due to the decline of collateral value, in order to cover the corresponding risk exposure, the bank may require the borrower to add additional collateral, which will further weaken the borrower's repayment ability, resulting in wrong way risk (WWR). 
3) Supply chain channel

Physical risk may affect the logistics network of the supply chain, resulting in poor circulation of upstream and downstream goods of the industry, affecting product circulation, and then causing financial difficulties for enterprises in the supply chain. The liquidity risk of enterprises may be transmitted along the upstream and downstream of the industrial chain, thus increasing the credit default risk faced by the supply chain finance department of the bank.

\subsection{Transformation Risk}

Transformation risk will have an impact on both the asset side and the liability side of banks, and its transmission path mainly includes the following three kinds:

\section{1) Climate policy risk}

With the implementation of carbon neutralization strategy, the government may introduce a series of policies to encourage low-carbon economy and decrease high-carbon enterprises, so as to increase the operating costs of high-carbon emission enterprises, affect their repayment ability, and then reduce the quality and return rate of corporate loans or bonds on such enterprises. The government may also introduce further measures to improve the risk-weighted assets (RWA) of high-carbon assets, so as to make banks hold more reserves for the high-carbon assets on their balance sheet, which will affect the liquidity level of these banks.

\section{2) Risk of stranded assets}

With the development of technology, the cost of new energy continues to decline. A large number of high-carbon assets represented by traditional energy enterprises will gradually lose market competitiveness and accelerate depreciation into stranded assets, resulting in a sharp decline in the asset value and return rate of the stranded assets held by banks.

\section{3) Bond valuation risk}

With the decline of the cash inflow of high-carbon enterprises under the background of carbon neutrality and the impact of climate related policy risks, the rating level of such enterprises may decline, which may affect the valuation level of their bonds, resulting in losses on the asset side of the banks holding these corporate bonds and increasing the risk of asset loss.

\section{Related Challenges}

For the asset-liability management of commercial banks, two types of risks are the focus: liquidity risk and interest rate risk. According to the above analysis on the transmission path of climate risk, we can summarize two key challenges brought by climate risk to bank's asset-liability management.

\subsection{Liquidity Risk}

The liquidity risk faced by the bank's asset-liability management mainly comes from the decrease of cash flow caused by the decline in the return on assets held by the bank.
The deterioration of asset quality also raises the capital requirement of banks by forcing the bank to hold more reserves to cover the increased risk exposure. This leads to a decline of the bank's capital adequacy ratio and an increase in capital demand and liquidity risk. On the other hand, with the development of new energy technology, the assets of the traditional energy industry will also depreciate into stranded assets. So the bank must value these assets at a higher discount rate, which reduces the liquidity of bank assets, forces the bank to sell more assets or increase active liabilities to maintain the liquidity level required by regulatory and operating needs.

\subsection{Interest Rate Risk}

The interest rate risk faced by bank's asset-liability management mainly comes from climate risk, which brings severe fluctuations to the market interest rate level through the transmission path we discussed above. On the one hand, physical risk can lead to the rise of capital demand of enterprises and residents, resulting in excessive savings, which incur an expansion of money supply and demand gap in the market. This results in a sharp fluctuation of market interest rate. On the other hand, due to the transformation risk, the risk weighted assets of high-carbon assets held by banks may rise under the influence of regulatory policies, which requires banks to raise capital to cope with the increased reserve level. With more capital need than supply, the rise of interbank borrowing market interest rate will be inevitable and thus increases the cost of bank liabilities. Due to the decline of return on high-carbon asset on the bank's balance sheet, the bank's net interest margin (NIM) is narrowed, which affects the bank's profitability level.

\section{Countermeasures}

By reasonably planning the asset structure held by the bank, strategically carrying out active liability management, reducing the liability side costs, and raising capital to deal with climate risks, the asset-liability management strategy of commercial banks can effectively improve the sustainable income of the bank's assets, deal with the pressure of narrowed net interest margin and enhance the liquidity risk buffer. A successful ALM strategy can play an important role in coping with climate risks.

\subsection{Asset Side}

On the asset side, the primary consideration of the bank is to optimize the asset structure on the premise of the existing liability scale and structure, and gradually get rid of high-carbon assets or stranded assets, so as to realize the long-term sustainable income on asset side. Commercial banks should start with internal funds transfer pricing (FTP), encourage the growth of green credit scale, and give different internal fund transfer prices to credit loans with different climate risk level through differentiated pricing strategies. In this way, the climate risk premium can be fully valued via the differentiated FTP, so as to promote a reasonable increase of the proportion of green assets. In terms of resolving high-carbon assets, we can refer to the total income swap agreement adopted by WWF in the disposal of stranded assets. 
By packaging and selling the income of stranded assets to the counterparty, we can swap the income of the stranded asset package with the income of a broader market portfolio of the counterparty, so as to reduce the risk brought by high-carbon assets.

\subsection{Liability Side}

On the liability side, the primary consideration of banks is to reduce the cost of liabilities to cope with the pressure of narrowing net interest margin caused by the decline of asset side income, which is incurred by climate risk. Banks should give priority to expand the scale of personal deposits, especially short-term deposits. Because the cost of personal deposits is lower and relatively stable than that of inter-bank borrowing and other active liability methods.

What's more, the bank should also consider expanding the scale of short-term deposits, which can reduce the bank's liability cost as the market-oriented reform of deposit interest rate goes on and the downward trend of deposit benchmark interest rate, which is the loan prime rate (LPR) in this case. In addition to reducing the scale of high interest deposits and increasing short-term low-cost deposits, banks can also carry out some active liabilities, such as issuing perpetual bonds, to take advantage of the low interest rate environment and reduce the liability costs.

\subsection{Capital Side}

On the capital side, the primary consideration of banks is to raise low interest funds to help expand green credit business, deal with the rising demand of reserve level and counter with the fluctuation of interest rate. Under the circumstances of narrowing net interest margin and increasing cost pressure on the liability side, banks can seize the conditions of favorable current policies and low interest rate of green financial bonds, to consider issuing green financial bonds. In this way, banks can improve the liability side structure, reduce the liability cost, support the development of green credit business and supplement the bank's medium and long-term low interest funds, which in the end, can improve the liquidity management ability of banks. At the same time, in the process of issuing green financial bonds, banks need to establish relevant ESG information disclosure mechanism, which can form market constraints on the bank's operation and management, to further encourage the standardization of its daily operation, and improve the bank's own operation and management ability.

\section{International Best Practices}

International best practices will be elaborated from three aspects: industry guidelines, regulatory policies and international banking practices:

\subsection{Industry Guidelines}

As a pioneer in climate risk management, TCFD issued the guidelines on climate risk management in October 2020 to help enterprises implement the guidelines on climate risk management in the guidelines. The guide proposes to combine climate risk management with corporate governance culture, strategic goal setting of the board of directors, business performance review, cross departmental information exchange and information disclosure. The integrated climate risk management plan proposed in the guide includes the following four aspects.

\section{1) Provide professional training}

By arranging relevant professional training, the front office and middle and back office employee should deeply understand the definition of climate risk and its potential impact on banking business operation. At the same time, talents of environmental-related majors should be recruited and a talent team with rich climate-related professional knowledge should be established to help the bank identify and control climate risk and assist customers to improve their climate risk prevention ability.

\section{2) Establish a framework}

The board of directors and senior management team should reach a consensus on climate risk management from the top. Both sides should clarify their part of responsibilities. They should also jointly formulate short-term, medium-term and long-term management objectives, plans and evaluation mechanisms. After this, the management team should incorporate climate risk management into the bank-wide comprehensive risk management framework, and continuously optimize and adjust risk appetite on a regular basis. By doing so, the company can cultivate its own internal climate risk management culture.

\section{3) Clarify responsibilities}

As climate risk will have a multi-dimensional and complex impact on each business line of the bank, the bank should match the sub categories of climate risk with the existing risk categories of the bank one by one, formulate corresponding climate risk management processes according to the existing risk classification, and clarify the allocation of human resources, supervision and feedback mechanism of each department.

\section{4) Innovate risk management tools}

Climate risk has strong uncertainty, so it is necessary to introduce new risk management tools to analyze its transmission path and mechanism, track the variation of potential climate risk factors, and evaluate the possible losses and action time under different scenarios. According to the suggestions of TCFD, banks should make full use of new tools such as scenario analysis and stress testing, establish an interdisciplinary team composed of professionals in finance and environmental science, develop more scientific risk measurement and management tools, and introduce new climate risk indicators.

\subsection{Regulatory Policy}

In 2019, British regulators - the Prudential Regulation Authority (PRA) and the Financial Conduct Authority (FCA) 
- jointly established the Climate Financial Risk Forum (CFRF). CFRF aims to effectively promote the financial sector to deal with the financial risks brought about by climate change, build cross financial industry taskforce and share the best practices of regulators and industries. Its members include representatives from the financial industry (including banks, insurance companies and asset management companies), and from PRA and FCA.

PRA has also recently become the world's first regulator to issue relevant regulatory expectations to guide banks and insurance companies to manage financial risks derived from climate change risks through the development of enhanced programs. The climate risk management framework described in the regulatory expectations issued by the PRA is divided into the following four aspects.

\section{1) Corporate governance}

The bank's board of directors should understand and assess the financial risks caused by climate change, be able to respond to and monitor these risks in the bank's overall business strategy, and determine relevant risk appetite. The risk appetite statement (RAS) issued by the board of directors shall formulate the climate risk exposure threshold, which is under the consideration of the bank's long-term financial interests and other factors, and fully take into account the variations of key risk drivers and external conditions that may affect the balance sheet. Responsibility for identifying and managing climate related financial risks should also be assigned to the relevant senior management officials.

\section{2) Risk management}

The bank should deal with the climate-related financial risks through the risk management framework established in accordance with the risk appetite approved by the board of directors. The company should establish corresponding processes to identify, measure, monitor, manage and report climate risk exposure. In addition, banks should consider adopting a range of quantitative and qualitative tools and indicators to monitor the financial risks they face from climate change. Banks should also try to understand the impact of physical risks on their customers and counterparties, as well as the potential impact of transformation risks on future investments.

\section{3) Scenario analysis}

Banks should assess their resilience and vulnerability to climate risk through scenario analysis. At the same time, the development of banking business should be evaluated in the short-term and long-term time scale, under the scenario of transition to low-carbon economy based on different transition paths. The results of such analysis will be used as a qualitative analysis of the board's strategic planning and decision-making, so as to select a low-carbon transformation path suitable for the bank.

\section{4) Information disclosure}

The bank's information disclosure report shall provide insightful information as much as possible to reflect that the bank has fully understood and has corresponding plans and means to deal with the financial risks brought by climate change.

\subsection{3 International Banking Best Practices}

From 2017 to 2018, Citigroup participated in the TCFD project and began to use scenario analysis tools to assess the climate risks faced by the whole bank under different scenarios. At present, Citigroup has incorporated the climate risk assessment process into its environmental and social risk management policy framework. The main measures include.

1) Fully consider the possible impact of climate risk on the debtor's business, assets and collateral in the credit business, and take the initiative to help the debtor reduce the impact of climate change on its financial situation.

2) Incorporate climate risk related factors into the bank wide business sustainability development strategy, so as to effectively avoid the direct impact of climate change on its own business; In addition, Citibank also supports customers' low-carbon transformation by providing customers with environmental financing services and tracking customers' climate risk level.

\section{Conclusion}

With the continuous emergence of the consequences of global warming, climate risk is changing from pure reputational risk to financial risk of commercial banks. In order to cope with the potential losses caused by climate risk to the bank's balance sheet, the asset-liability management department of commercial banks shall take the lead in formulating the bank wide overall action plan.

On the asset side, we should gradually reduce high-carbon assets, expand the scale of green credit, increase the holdings of green industry bonds, and guide the optimization of asset structure through differentiated FTP accurate pricing. On the liability side, we should expand the scale of low-cost liabilities, such as deposits, reduce long-term high-cost liabilities and reduce the overall debt cost. On the capital management side, we should seize the market opportunity to timely issue green bonds or perpetual bonds, accumulate the bank's capital buffer, and provide sufficient capital reserves and liquidity buffer for the bank's green transformation.

The implementation of the whole scheme requires the close cooperation of the asset-liability management department, corporate banking and personal banking business lines and risk management department, so as to realize the steady operation and sustainable development of commercial banks.

\section{References}

[1] Liu Ruixia, "How banks deal with climate risk under the vision of carbon neutrality", Tsinghua Financial Review, (04), pp. 44-46, 2021.

[2] Liu Xiaoshu, Yang Jingcheng, “Commercial banks should pay attention to financial risks caused by climate related risks", Contemporary financier, (07), pp. 96-98,2021. 


\section{Author Profile}

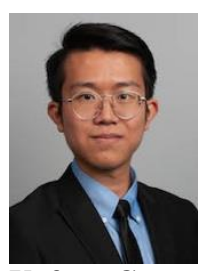

Yufeng Guo received the B.S. degree in Electrical Engineering from Beijing Institute of Technology in 2019 and the M.S. degree in Management Studies from the Fuqua School of Business, Duke University in 2020. He is now with the Agricultural Bank of China, Head Office and pursuing a M.S. degree in finance from Renmin University of China. 